\title{
Impact of Formal Climate Risk Transfer Mechanisms on Risk-Aversion: Empirical Evidence from Rural Ethiopia
}

Citation for published version (APA):

Haile, K. K., Nillesen, E., \& Tirivayi, N. (2020). Impact of Formal Climate Risk Transfer Mechanisms on Risk-Aversion: Empirical Evidence from Rural Ethiopia. World Development, 130, [104930]. https://doi.org/10.1016/j.worlddev.2020.104930

Document status and date:

Published: 01/06/2020

DOI:

10.1016/j.worlddev.2020.104930

Document Version:

Publisher's PDF, also known as Version of record

Document license:

Taverne

Please check the document version of this publication:

- A submitted manuscript is the version of the article upon submission and before peer-review. There can be important differences between the submitted version and the official published version of record.

People interested in the research are advised to contact the author for the final version of the publication, or visit the DOI to the publisher's website.

- The final author version and the galley proof are versions of the publication after peer review.

- The final published version features the final layout of the paper including the volume, issue and page numbers.

Link to publication

\footnotetext{
General rights rights.

- You may freely distribute the URL identifying the publication in the public portal. please follow below link for the End User Agreement:

www.umlib.nl/taverne-license

Take down policy

If you believe that this document breaches copyright please contact us at:

repository@maastrichtuniversity.nl

providing details and we will investigate your claim.
}

Copyright and moral rights for the publications made accessible in the public portal are retained by the authors and/or other copyright owners and it is a condition of accessing publications that users recognise and abide by the legal requirements associated with these

- Users may download and print one copy of any publication from the public portal for the purpose of private study or research.

- You may not further distribute the material or use it for any profit-making activity or commercial gain

If the publication is distributed under the terms of Article 25fa of the Dutch Copyright Act, indicated by the "Taverne" license above, 


\title{
Impact of formal climate risk transfer mechanisms on risk-aversion: Empirical evidence from rural Ethiopia
}

\author{
Kaleab K. Haile ${ }^{\mathrm{a}, \mathrm{b}, *}$, Eleonora Nillesen ${ }^{\mathrm{a}, \mathrm{b}}$, Nyasha Tirivayi ${ }^{\mathrm{a}}$ \\ a UNU-MERIT, Netherlands \\ ${ }^{\mathrm{b}}$ Maastricht Graduate School of Governance, Maastricht University, Netherlands
}

\section{A R T I C L E I N F O}

\section{Article history:}

Accepted 19 February 2020

Available online 4 March 2020

\section{JEL classification:}

C91

D03

I38

N27

\section{Keywords:}

Weather index-based crop insurance

Endogenous risk preferences

Experimental risk elicitation

Endogenous switching probit

Sub-Saharan Africa

Ethiopia

\begin{abstract}
A B S T R A C T
This study examines the effect of smallholder farmers' access to a formal climate risk transfer mechanism on their risk preferences. Survey and experimental data were collected from smallholder farmers that have access to weather index-based crop insurance (WICI) in Ethiopia. We use an endogenous switching probit (ESP) model to address self-selection and simultaneity biases. Results from the ESP model show that farmers who purchased WICI are less likely to be risk-averse compared with the counterfactual scenario of being non-purchaser farmers. Similarly, non-purchasers would have attained a significant reduction in their risk-aversion if they had taken up the insurance product. We also find that WICI has a positive and statistically significant effect on farmers' real-life risk-taking behavior as exemplified by mineral fertilizer use. The implication of our findings is that formal climate risk transfer mechanisms can positively influence rural household farm investment decisions, by reducing individual riskaversion. Therefore, they can possibly contribute to poverty alleviation and economic development within agrarian economies that are exposed to recurrent and severe climate shocks.
\end{abstract}

(c) 2020 Elsevier Ltd. All rights reserved.

\section{Introduction}

Agricultural households in sub-Saharan Africa (SSA) are facing more frequent and severe climate risks than ever before (Masih, Maskey, \& Trambauer, 2014; Shiferaw et al., 2014). The absence or inaccessibility of formal credit and insurance markets limits the ability of agricultural households to withstand the effects of climate shocks (Karlan, Osei, Osei-akoto, \& Udry, 2014), and has been a key determinant of longer-term poverty dynamics (Chantarat, Barrett, Mude, \& Turvey, 2007; Barnett, Barrett, \& Skees, 2008). In the presence of uninsured weather shocks, any reduction in farming households' agricultural production can have detrimental impacts on food and income available for consumption (Hertel \& Rosch, 2010). Hence, most households respond by altering their economic behavior and decisions, which have repercussions on their production. In this respect, it is generally assumed that

\footnotetext{
* Corresponding author at: Boschstraat 24, 6211 AX Maastricht, Netherlands. E-mail addresses: haile@merit.unu.edu, k.haile@maastrichtuniversity.nl (K.K. Haile), nillesen@merit.unu.edu, eleonora.nillesen@maastrichtuniversity.nl (E. Nillesen), tirivayi@merit.unu.edu (N. Tirivayi).
}

farmers in developing countries are risk-averse as an ex-ante response to minimize the climate shock-induced income variability that they frequently experience. Accordingly, the households will "self-insure" by engaging in low-risk low-return agricultural activities (Rosenzweig \& Binswanger, 1993) which in the shortrun may seem sub-optimal. However, in the long-term, risk aversion ultimately traps agricultural households in persistent poverty (Carter \& Barrett, 2006; Yesuf \& Bluffstone, 2009; Dercon \& Christiaensen, 2011).

Risk-aversion is a significant determinant of households' decisions that lead to: low investments in higher-income farm enterprise combinations (Nyikal \& Kosura, 2005), assigning a lower value to education attainment (Brown, Fang, \& Gomes, 2012), and low adoption of agricultural technologies (Liu, 2013; Ward \& Singh, 2015; Brick \& Visser, 2015; Holden \& Quiggin, 2017). At the aggregate level, households' low investments in physical and human capital may further aggravate the productivity lag and income inequality in rural areas of SSA (Odusola et al., 2017), where high inequality has constrained poverty reduction efforts (Fosu, 2015). Hence, risk-aversion is linked to development prospects of a country by influencing households' production, 
consumption, and labor supply decisions which in turn determine the accumulation of human, physical, and financial capital.

In light of this, there has been a growing interest in developing weather index-based crop insurance (WICI) schemes that provide a transparent risk transferring mechanism for smallholder farmers to help them better manage climate risks and exhibit risk-taking behavior in their agricultural practices (Barnett et al., 2008). Few studies analyze the impact of WICI on households' decision to invest in high-risk high-return activities (Hill \& Viceisza, 2012; Mobarak \& Rosenzweig, 2012; Karlan et al., 2014). These studies examine how improving access to formal insurance markets affects farmers' willingness to take risky investment decisions using field experiments in developing countries. However, such an approach simultaneously captures risk preferences, beliefs about the background risk (i.e. uninsurable idiosyncratic risks associated with the investment), and opportunities to engage in a given behavior (e.g. available investment options) (Schildberg-hörisch, 2018). Furthermore, these studies implicitly take risk preferences as stable over time and exogenous in the WICI impact pathways. Hence, the fixity of farmers' risk preferences is assumed rather than measured an approach akin to the canonical economic model of decision-making. Although standard economic models assume exogenous and stable preferences (Friedman, 1962; Stigler \& Becker, 1977) overlooking the fundamental endogeneity of preferences would limit the insights that could be gained from examining household decision-making (Becker \& Mulligan, 1997; Krackhardt, 1998; Netzer, 2009). "If preferences are affected by the policies or institutional arrangements we study, we can neither accurately predict nor coherently evaluate the likely consequences of new policies or institutions without taking account of preference endogeneity" (Bowles, 1998). Therefore, ignoring the endogeneity of risk preferences restricts an empirical inquiry into a plausible mechanism through which risk management policy or program interventions may influence households' economic decisions and outcomes.

Risk preferences and the availability of institutions that facilitate risk bearing are not independent (Roumasset, 1976; Eswaran \& Kotwal, 1986; Mendola, 2007). Empirical studies by Gloede, Menkhoff, and Waibel (2015) and Sakha (2019) show that the exposure of rural households to uninsured weather anomalies increases individual risk-aversion. ${ }^{1}$ We hypothesize that farmers' access to WICI - a climate risk transfer mechanism - could be a stimulus that may have a reverse effect. As such, improving rural households' access to formal climate risk transfer mechanisms that buffer the households' livelihood from the effects of weather shocks may reduce farmers' risk-aversion. To date, empirical studies have not explored this possibility as they have focused on the effects that farmers' risk preferences have on the uptake of WICI as demonstrated in Giné, Townsend, and Vickery (2008), Cole et al. (2013), Hill, Hoddinott, and Kumar (2013), Karlan et al. (2014), and Jin, Wang, and Wang (2016). However, the implicit assumption that farmers' risk preferences are exogenous and cannot be changed may be excessive (Melesse \& Cecchi, 2017). Our study contributes to the literature by examining the impact of agricultural households' access to WICI on their risk-aversion, while taking into account the endogeneity of both risk preferences and WICI uptake. The sources of endogenous WICI uptake are: (i) the effect of risk preferences on WICI uptake (simultaneity bias), and (ii) the effect of unobserved heterogeneity among farmers that can simultaneously affect risk preferences and WICI uptake (self-selection bias).

Our study is set in Ethiopia, where devastating negative rainfall shocks are ubiquitous (Suryabhagavan, 2017). The study provides

\footnotetext{
${ }^{1}$ The evidence on the impact of climate shocks on individual risk preferences using cross-sectional data in Gloede et al. (2015) is consistent with the findings of Sakha (2019) that use panel data.
}

valuable insights into the structural relationship between a pilot program intervention that facilitates access to WICI and farmers' risk preferences. We rely on an experimental incentivecompatible risk elicitation method, which according to Charness, Gneezy, and Imas (2013) and Meyer (2014) enables researchers to obtain an isolated measure of farmers' utility curvature parameters - risk preferences. In so doing, we analyze the impact of WICI on farmers' risk preferences and explore one of the possible causes of change in risk-aversion. Our study contributes to the small but growing literature on the effects of markets on individual riskaversion (see Section 2 for a review). Outside the context of markets, there are also few but growing number of empirical studies that show changes in risk-aversion due to individual's exposure to conflict and violence (Voors et al., 2012; Callen, Isaqzadeh, Long, \& Sprenger, 2014; Moya, 2018; Jakiela \& Ozier, 2019), climate shocks and natural disasters (Eckel, El-gamal, \& Wilson, 2009; Cameron \& Shah, 2015; Gloede et al., 2015; Cassar, Healy, \& Kessler, 2017; Hanaoka, Shigeoka, \& Watanabe, 2018; Sakha, 2019), and financial shocks (Malmendier \& Nagel, 2011; Cohn, Engelmann, Fehr, \& Maréchal, 2015).

We utilize data collected from 240 smallholder farmers with access to a WICI scheme in Northern Ethiopia. Household survey data were collected from insured and uninsured agricultural households. We conducted a simple unframed risk experiment to elicit individual risk preferences using incentive compatible lotteries that involve a choice between a sure amount and a lottery with two varying pay-offs but equal probability as presented in Brick, Visser, and Burns (2012). We use a simultaneous equations model (SEM) and an endogenous switching probit (ESP) model to estimate the impact of WICI on the risk-aversion of farmers, after adjusting for observed covariates. Our results from the preferred model (i.e. ESP) show that there is significant positive selfselection for non-purchaser farmers. Risk-aversion and the decision not to buy WICI are perfectly correlated. We observe a negative selection effect for the purchaser farmers, but it is not statistically significant. The impact estimates show that WICI significantly decreases the risk-aversion of farmers. On average, the risk-aversion of farmers who have purchased WICI is significantly lower than what it would have been had they not purchased the insurance product. Similarly, the risk-aversion of non-purchaser farmers would have also been reduced if they had taken up WICI. Moreover, if every farmer in the study area is insured, the proportion of risk-averse farmers would decline by 35 percentage points. If WICI uptake changes risk-aversion, we should also plausibly observe that in real-life behavior, which we do: WICI increases mineral fertilizer use. Therefore, WICI uptake can change farmers' interpretation of the operating environment for farming and ultimately reduces their risk-aversion - a major driver of agricultural technology adoption.

Our research on the endogeneity of risk preferences in relation to insurance markets is conceptually relevant to explain economic decisions of agricultural households in the presence of climate risks. The findings of our study have important implications for policy and program interventions that intend to spur economic development in agrarian economies in the era of frequent and severe climate shocks. Since formal climate risk transfer mechanisms significantly reduce farmers' risk-aversion, investments on risk management policies and strategies can have long-term effects on agricultural households by bringing up desirable economic behavior that may enable them to break out of poverty traps and enjoy virtuous cycle of increasing income.

The remainder of the paper is organized as follows. Section 2 reviews prior works that provide a link between (insurance) markets and households' preferences and behavior. Section 3 describes the insurance product, and presents the source of data and 
methods of data analysis. Section 4 presents the descriptive and econometric results of the study, and the discussion based on the results. Section 5 concludes.

\section{Literature}

\subsection{Agricultural households, crop insurance markets, and risk-taking behavior}

At the heart of agricultural households economic model is the issue of whether production, consumption, and labor supply decisions are simultaneously determined or if they are separable. In true subsistence farming, a household consumes what it produces and must rely exclusively on its own resources (Singh, Squire, \& Strauss, 1986). Hence, production, consumption and labor supply decisions are non-separable. The majority of agricultural households in developing countries are semi-commercial farms in which some inputs are purchased and some outputs are sold. If competitive markets exist for factors of production, outputs, and credit and insurance, prices are exogenous and (climate and market) risks can be completely diversified resulting in a separable or non-recursive decision-making process (Roe \& Graham-Tomasi, 1985). As such, production decisions (input use, adoption of farm technologies, and output choice) affect consumption via food production and income levels, and those production decisions are entirely independent of consumption.

However, in most developing countries, markets related to land, inputs, credit, insurance, and some basic commodities are incomplete, function poorly or may have high transaction costs for agricultural households (de Janvry, Fafchamps, \& Sadoulet, 1991). Hence, the decision process becomes non-separable (circular) (Singh et al., 1986; Taylor \& Adelman, 2003; Mendola, 2007); a farming household as a consumer affects its behavior as a producer, and vice versa. In the presence of climate risks, as an adaptive response, farmers usually modify their production practices to safer but low-return activities as a means of providing selfinsurance to smooth consumption (Rosenzweig \& Binswanger, 1993). In these circumstances, liquidity constraints generated by market imperfections shape agricultural households' decisions and behavioral responses that determine their immediate and long-term income generating capacity.

Recently, field experiments have been carried out in developing countries to estimate the causal effect of relaxing insurance market constraints on the households' tendencies to invest in agricultural activities that are risky but highly profitable. Hill and Viceisza (2012) conduct a framed field experiment in rural Ethiopia to examine farmers' decision whether to invest in mineral fertilizers or not in the presence of an insurance market. They found that farmers' uptake of the insurance product has a positive effect on fertilizer purchases. In a randomized experimental setting in rural India, Mobarak and Rosenzweig (2012) find that rice farmers that were offered the index insurance product plant less drought resistant (high-risk) but high-yield rice varieties, which may bear desirable welfare effects on these households by improving both food availability and income. Similarly, Karlan et al. (2014) randomly assigned farmers in Ghana in three treatment arms to receive cash grants, premiums to purchase rainfall index insurance, or a combination of the two. They find that the rainfall insurance triggers agricultural investments and risky production choices with higher expected returns compared to the means of the control group farmers. All the studies mentioned above show the impact of WICI on farmers' risk-taking in agricultural investment decisions but not on their risk preferences per se. Our study examines the presence of a causal relationship between farmers' access to insurance markets and their risk preferences.

\subsection{Markets and endogenous risk preferences}

The standard economic assumption of fixed and exogenously determined preferences has submerged the economic thought that the natural, social, economic, financial, and political environment may shape preferences of individuals. The assumption of exogenous and stable risk preferences implies that one should obtain the same estimate of a curvature parameter of the utility function when measuring an individual's risk preferences repeatedly. However, this has not been the case in most recent empirical studies which show systematic variations in the parameter that characterizes an individual's risk preferences (see Schildberg-hörisch (2018) for a recent review). The endogeneity of preferences implies that policies and institutional arrangements affect the evolution of tastes and values regarding consumption, investment, and other socio-economic activities (Bowles, 1998). Changes in economic institutions, such as markets, signal different stimuli to people and influence them to perceive a different world, which leads to changes in values and preferences (Bowles, 1998; Gerber \& Jackson, 1993).

In this regard, Palacios-Huerta and Santos (2004) developed a general equilibrium framework to examine the endogenous formation of preferences associated with the extent of credit market completeness in Bangladesh. The primary empirical prediction of the model is that risk-aversion attitudes will be endogenously related to credit market arrangements. They used the worst floods that the country experienced in 1988 as exogenous variation, which segmented the existing micro-credit institutions, to compare individual risk attitudes during this situation and the more normal circumstances of 1992 . They provide estimates of riskaversion coefficients that are significantly lower for households where credit markets appear to be well-functioning relative to the poorly functioning counterfactual. Melesse and Cecchi (2017) use an artefactual field experiment in Ethiopia to offer insights into changes in individuals' risk preferences as a result of their exposure to output markets. Their empirical analyses reveal that farm households with greater market experience are more risk tolerant. They indicate that risk-aversion is a trait that can be endogenously changed through increasing the households' exposure to markets, and thus the claim that farm households are inherently riskaverse may be excessive. To the best of our knowledge, our study is the first empirical investigation that attempts to establish a causal relationship between farmers' access to crop insurance market and risk-aversion.

\section{Methodology}

\subsection{Description of the WICI scheme}

This study evaluates the WICI scheme in Ethiopia. The existing scheme is the continuation of the Horn of Africa Risk Transfer for Adaptation (HARITA) pilot program which was initiated in 2009 insuring 200 households in one district in Tigray regional state of Ethiopia. Building on the success of HARITA, the R4 rural resilience initiative emerged in 2011, bringing together a network of partners including the World Food program (WFP), Oxfam America (OA), Relief Society of Tigray (REST), Nyala Insurance Share Company, Africa Insurance Company, Dedebit Credit and Savings Institution (DECSI), Mekelle University, and the International Research Institute for Climate and Society (IRI) (Madajewicz, Tsegay, \& Lee, 2017).

The main objective of R4 is to enable farmers manage climate risks and attain food and income security. In 2017, R4 reached a total of more than 31, 942 farming households in 11 districts in Tigray and 1 district in Amhara national regional states of Ethiopia 
(WFP/OA, 2018). ${ }^{2}$ The crop insurance product under the R4 initiative covers major cereals (i.e. teff, wheat, barley, maize, and sorghum) that are widely produced in the study Tabias, which are the smallest administrative units within a district. Insurance enrollment usually takes place between March and June. During the survey period, farmers paid a premium of 160 ETB for a single insurance coupon that paid out on average 800 ETB. The WICI scheme also has an insurance-for-work component which allows farmers to pay their premium by providing their labor to the public works of the national safety net program (PSNP) (Madajewicz et al., 2017).

A unique aspect of the WICI scheme under the R4 initiative is the comprehensive strategy that is implemented to handle the issue of weather-related basis risk. Basis risk is an inherent problem to index insurance such that there is a mismatch between the index-triggered payouts and the actual losses suffered by farmers. The WICI scheme has a separate R4 basis risk fund to ensure that losses are compensated for farmers in areas where the index has not adequately captured negative rainfall shocks, and these payments are made at the same time as the insurance payouts (WFP/OA, 2018). Therefore, the WICI under the R4 initiative is more risk-free than the common index-based insurance products in other developing countries. Currently, the R4 initiative expanded to reach farmers in Senegal, Malawi, Zambia, Kenya and Zimbabwe (WFP/OA, 2018).

\subsection{Source and type of data}

This study is based on data collected from farmers that reside in tabias with access to WICI in Tigray regional state of Ethiopia. We collected primary data from insured and uninsured farming households using a household survey and an incentivized risk experiment. A multistage random sampling method was employed to generate a total sample of 240 agricultural households. Tigray regional state has a total of 34 districts. $\mathrm{R} 4$ is operating in 11 districts where each district comprises of 15 to 20 tabias, and not all the tabias in the R4 districts have access to the WICI. Therefore, we take this into account in our multistage random sampling procedure. First, we randomly selected 2 districts (namely Alamata and Raya Azebo) from the list of 11 districts with some of their tabias having access to WICI. Then, from a total of 16 tabias that have access to WICI in the two districts, five (two from Alamata and three from Raya Azebo) were randomly picked. Finally, we randomly selected a total of 120 purchaser and 120 non-purchaser households from the five tabias. A structured questionnaire was prepared to collect socioeconomic data that focus on the demographic, agronomic and institutional variables in the 2017 farming season.

As part of the larger survey, an unframed incentivized risk experiment was also carried out individually to elicit the risk preferences of the sample farmers. Incentivized experiments are regarded as appropriate because they minimize self-serving biases, inattention, and strategic motives that distort self-reported risk attitudes (Camerer \& Hogarth, 1999). This paper utilized the experimental game protocol outlined by Brick et al. (2012), ${ }^{3}$ which allows classifying risk-aversion categories based on expected utility theory (EUT). A simple game protocol, similar to the one we used in this study, is a reliable measurement tool of risk preferences in a mostly illiterate sample (Dave, Eckel, Johnson, \& Rojas, 2010) and

\footnotetext{
2 The R4 pilot WICI scheme in Ethiopia is implemented in districts that suffer severe and frequent drought shocks. However, some of the tabias in the R4 districts do not have access to WICI. These tabias are excluded because of a mismatch between the historical drought seasons that the households reported and the satellite rainfall data (upon which the index is computed).

${ }^{3}$ We maintain the original design as outlined by Brick et al. (2012), but we used fewer decision tasks to make the risk elicitation experiment as simple as possible without compromising its construct validity.
}

adequately captures differences in individual risk preferences (Charness et al., 2013). The risk preferences elicitation experiment was administered individually after the completion of the survey. ${ }^{4}$ The maximum possible earnings from the experiment were 20 $\mathrm{ETB}^{5}$ with subjects receiving $11.30 \mathrm{ETB}$ on average. This amount is higher than the opportunity cost of their time spent participating in the experiment and hence ensures a salient incentive for the farmers to make their decisions carefully. ${ }^{6}$

As depicted in Table 1, after a practice round, the experimenter asked each farmer to make five choices involving real money. Each choice (task) is a decision between picking a sure amount of money in option A, and tossing a coin in option B to earn either 20 ETB if the head comes up or nothing, if tail did. While farmers made decisions on five tasks, only one was randomly picked to determine their earnings. Since they could not know in advance which task will that be and each task has an equal chance of being used in the end, subjects are expected to think carefully about which option they prefer in each task. The first task is a rationality check and merely tests whether the participants understood the game. We also enforced monotonicity - if they switched they should switch from option A to option B only once. One subject, however, shifted between option A and option B multiple times. Consequently, the subject was excluded from the analysis because the range of the risk preference parameter could not be computed. Hence, we are left with a sample of 239 heads of smallholder farming households for our analyses.

We followed the constant relative risk-aversion (CRRA) ${ }^{7}$ utility function to compute the range of the risk preference parameter at each task where the switch could happen. Based on these ranges, we classified the risk preferences of farm households into four categories - risk-takers, risk-neutral, risk-averse, and highly risk-averse ${ }^{8}$. For instance, for a given farmer who shifted from option A to option $B$ in the second task the range of the risk preference parameter $(-1.41<r<0)$ is computed as compound inequalities given by;

$$
\frac{20^{1-r}}{1-r}>\frac{0.5 \times 20^{1-r}}{1-r} \text { and } \frac{15^{1-r}}{1-r}<\frac{0.5 \times 20^{1-r}}{1-r}
$$

Based on Table 1, our ordinal risk preferences variable entails the four risk preference categories, ordered, based on the level of risk-aversion as follows;

$$
\text { Riskpreferences }= \begin{cases}1 & \text { if risk-taker } \\ 2 & \text { if risk-neutral } \\ 3 & \text { if risk-averse or highly risk-averse }\end{cases}
$$

Moreover, to facilitate the estimation of treatment effects using a small sample and more flexible model specification, following Cameron and Shah (2015) and Jakiela and Ozier (2019) we converted our ordinal risk preference dependent variable into a binary variable. We framed the binary variable to indicate risk-aversion of farmers as follows;

$$
\text { Riskaverse }= \begin{cases}1 & \text { if risk-averse or highly risk-averse } \\ 0 & \text { if risk-neutral or risk-takers }\end{cases}
$$

\footnotetext{
${ }^{4}$ Appendix $A$ in the supplementary materials presents the instruction for the risk experiment.

${ }^{5}$ One ETB is 0.044 U.S. Dollar based on the survey period average official exchange rate, which is obtained from OANDA currency converter http://www.oanda.com/ currency/converter.

${ }^{6}$ Public works participation in the districts pays 14 ETB per day during the survey period.

${ }^{7}$ CRRA states that the degree of risk-aversion remains constant when both the monetary payoff of the lotteries and wealth increase proportionally. Under CRRA utility function, the range of the risk preference parameter is computed as; $u=\frac{x^{1-r}}{1-r}$.

${ }^{8}$ The highly risk-averse farmers are those who shifted at the 5th task or those who did not shift at all (i.e those who chose option A throughout).
} 
Table 1

Experimental game tasks and elicited risk preferences.

\begin{tabular}{|c|c|c|c|c|c|}
\hline \multirow[t]{2}{*}{ Task } & \multirow{2}{*}{$\begin{array}{r}\text { Option A } \\
\text { Sure Amount }\end{array}$} & \multicolumn{2}{|c|}{ Option B } & \multirow{2}{*}{$\begin{array}{l}\text { Risk-preference } \\
\text { Parameter range }\end{array}$} & \multirow{2}{*}{$\begin{array}{r}\text { Risk-preference } \\
\text { Category }\end{array}$} \\
\hline & & Outcome 1 & Outcome 2 & & \\
\hline 1 & 20 & $20 ; \frac{1}{2}$ & $0 ; \frac{1}{2}$ & $r<-1.4$ & Rationality-check \\
\hline 2 & 15 & $20 ; \frac{1}{2}$ & $0 ; \frac{1}{2}$ & $-1.41<r<0$ & Risk-takers \\
\hline 3 & 10 & $20 ; \frac{1}{2}$ & $0 ; \frac{1}{2}$ & $0<r<0.42$ & Risk-neutral \\
\hline 4 & 6 & $20 ; \frac{1}{2}$ & $0 ; \frac{1}{2}$ & $0.42<r<0.7$ & Risk-averse \\
\hline 5 & 2 & $20 ; \frac{1}{2}$ & $0 ; \frac{1}{2}$ & $0.7<r$ & Highly risk-averse \\
\hline
\end{tabular}

The last two columns are not shown or told to the subjects.

\subsection{Identification strategy}

Using a naïve ordered probit model, the effect of WICI on the risk preferences of farmers can be estimated by regressing the latent variable representing the propensity of risk-aversion of farmer $i\left(Y_{i}^{*}\right)$ on the WICI uptake of the farmer $\left(T_{i}\right)$ and a vector of household characteristics $\left(x_{i}\right)$ assuming exogenous WICI uptake - the correlation between the error term $\left(\omega_{1 i}\right)$ and $T_{i}$ is zero. $\alpha$ and $\beta_{1}$ are unknown parameters to be estimated.

$Y_{i}^{*}=\alpha T_{i}+x_{i} \beta_{1}^{\prime}+\omega_{1 i}, \omega_{1} \sim \mathscr{N}\left(0, \sigma^{2}\right)$

where the subscripts indicate variation over farmers $(\mathrm{i}=1,2, \ldots, \mathrm{N})$. The latent risk-aversion variable $\left(Y_{i}^{*}\right)$ and thresholds $\left(\eta_{1}\right.$ and $\left.\eta_{2}\right)$ are not directly observed. Instead, we only observe

$Y_{i}=\left\{\begin{array}{cc}1 & \text { if } Y_{i}^{*} \leqslant \eta_{1} \\ 2 & \text { if } \eta_{1}<Y_{i}^{*} \leqslant \eta_{2} \\ 3 & \text { if } Y_{i}^{*}>\eta_{2}\end{array}\right.$

For this study, however, the assumption of exogenous WICI uptake decision of farmers is unrealistic due to self-selection and simultaneity biases. Hence, the ordered probit specification may result in biased estimates on the causal effect of purchasing WICI on the level of risk-aversion of farmers. To address the problem of endogeneity in Eq. 1, we use a maximum likelihood estimator of an ordinal outcome with a binary endogenous regressor under the simultaneous equations model (SEM). Maximum likelihood estimators have the properties of being consistent and asymptotically efficient (Greene, 2012). The SEM jointly determines Eqs. (1) and (2) as a system of two equations that allows risk preferences to be correlated with the binary WICI uptake choice in Eq. 2, and WICI uptake to be an endogenous regressor in the ordinal risk preferences outcome variable in Eq. 1. This enables us to estimate the coefficient on $T_{i}(\alpha)$ as the unbiased measure for the average treatment effect (ATE) - the average effect of changing the whole population from being non-purchasers to purchasers of WICI. The binary endogenous WICI uptake is modeled as;

$T_{i}^{*}=x_{i} \beta_{2}^{\prime}+\gamma Z_{i}+\omega_{2 i}, \omega_{2} \sim \mathscr{N}\left(0, \sigma^{2}\right)$

where, the $i^{\text {th }}$ farmer's propensity to purchase WICI $\left(T_{i}^{*}\right)$ is a latent continuous variable for which only the binary variable $T_{i}$ is observed such that;

$T_{i}= \begin{cases}0 & \text { if } T_{i}^{*} \leq 0 \\ 1 & \text { if } T_{i}^{*}>0\end{cases}$

where $x_{i}$ is a vector of variables identical to the one in Eq. 1 and $Z_{i}$ is an instrumental variable (IV). The SEM model is generally identified even in the absence of the excluded variable $\left(Z_{i}\right)$. However, to improve identification we used a binary variable that indicates whether farmers live in the same village with the insurance foreman as the excluded variable from Eq. 1. Nigus, Nillesen, and Mohnen (2018) used a similar IV in their analysis on the effect of WICI on social capital. The rationale behind choosing this IV is that the insurance foremen are tasked for promoting and creating awareness among farmers about WICI. We, therefore, hypothesized farmers are likely to have better knowledge and attitudes about WICI if the foreman lives in the village they belong to, and ultimately influence their decision to opt for the insurance uptake. Moreover, the assignment of the foremen are an administrative level decision which is independent of the households' risk behavior. $\alpha, \gamma, \beta_{1}$ and $\beta_{2}$ are unknown parameters to be estimated. $\left(\omega_{1 i}, \omega_{2 i}\right)^{\prime}$ is a vector of error terms that follows a bivariate standard normal distribution with correlation coefficient $\rho$ described as;

$\left(\begin{array}{ll}\omega_{1 i} & \omega_{2 i}\end{array}\right)^{\prime} \sim \mathscr{N}\left(\left(\begin{array}{ll}0 & 0\end{array}\right)^{\prime},\left[\begin{array}{ll}1 & \rho \\ \rho & 1\end{array}\right]\right)$

We also used a full information maximum likelihood (FIML) under the endogenous switching probit (ESP) model to take into account the interdependencies between WICI uptake and separate equations for the outcome variables (i.e. risk-aversion and mineral fertilizer use) of purchasers and non-purchasers. ESP is a more flexible specification than SEM since it allows the effects of household characteristics on the outcome variables to vary between the purchaser and non-purchaser farmers. Consequently, besides the ATE, we can also estimate the average treatment effect on the treated (ATT) and average treatment effect on the untreated (ATU). The ATT is the average effect of WICI on those farmers who have purchased the insurance. The ATU is the average effect of WICI on the riskaversion of non-purchasers had they decided to uptake the insurance.

The ESP model simultaneously considers a binary outcome variable - risk-aversion or fertilizer use - that describes the behavior of farmers with two regimes (Eqs. 3 and 4) and a switch (selection) function (Eq. 2) that determines which regime the farmer faces. Along with Eq. 2, the ESP can be specified as a system of equations for latent variables as;

$Y_{1 i}^{*}=x_{1 i} \tau_{1}^{\prime}+\varepsilon_{1 i}$

$Y_{0 i}^{*}=x_{0 i} \tau_{0}^{\prime}+\varepsilon_{0 i}$

where the observed farmer's WICI uptake decision is as defined under Eqs. 2. $Y_{1} i^{*}$ and $Y_{0} i^{*}$ are the latent variables for the binary outcome variable of the purchasers and non-purchasers respectively. The observed $Y_{i}$ is defined as:

$Y_{i}= \begin{cases}Y_{1 i} & \text { if } Y_{1 i}^{*}>0 \text { and } T_{i}=1 \\ Y_{0 i} & \text { if } Y_{0 i}^{*}>0 \text { and } T_{i}=0\end{cases}$

Moreover: $x_{1 i}$ and $x_{0 i}$ are vectors of explanatory variables; $\gamma, \beta_{2}, \tau_{1}$ and $\tau_{0}$, are unknown parameters to be estimated; and $\omega_{2 i}, \varepsilon_{1 i}$, and $\varepsilon_{0 i}$ are the error terms which are jointly normally distributed with a mean-zero vector and correlation matrix:

$\Omega=\left(\begin{array}{ccc}1 & \rho_{0} & \rho_{1} \\ & 1 & \rho_{10} \\ & & 1\end{array}\right)$ 
where $\rho_{0}, \rho_{1}$ and $\rho_{10}$ are the correlations between $\varepsilon_{0}$ and $\omega_{2}, \varepsilon_{1}$ and $\omega_{2}$, and $\varepsilon_{1}$ and $\varepsilon_{0}$ respectively. While $\rho_{10}$ can not be estimated, $\rho_{0}$ and $\rho_{1}$ are identified since the data provide information on the correlations (Miranda \& Rabe-Hesketh, 2006). If $\rho_{0} \neq \rho_{1} \neq 0$, treating WICI as an exogenous variable delivers inconsistent estimator because WICI uptake decision is correlated with $\varepsilon_{0}$ and $\varepsilon_{1}$ (Huang, Raunikar, \& Misra, 1991). As such, $\rho_{0}$ and $\rho_{1}$ capture the extent to which risk-aversion affects WICI uptake decision of nonpurchasers and purchasers, respectively.

The ESP analysis also does not require exclusion restrictions to identify treatment effects since the model can be identified by the non-linearities in the inverse mills-ratio using two-step estimation method (Heckman, 1978). As a consequence, ESP model can be estimated without $Z_{i}$ such that $x_{i}, x_{1 i}$ and $x_{0 i}$ contain identical elements. However, Maddala (1983) noted that specifying at least one exclusion restriction better identify the selection mechanism and FIML estimation method is more efficient than two-step estimation procedures to estimate ESP. To that end, we used the binary variable that captures whether the foreman lives in the same village with the household as the excluded variable from the vectors $x_{1 i}$ and $x_{0 i}$. Following Aakvik, Heckman, and Vytlacil (2005) and Lokshin and Sajaia (2011), after estimating the parameters of the ESP model using FIML method, we can compute endogeneity-bias corrected estimates of the variant treatment effect measures ATT Eq. (5), ATU Eq. (6), and ATE Eq. (7) - as:

$$
\begin{aligned}
A T T & =E\left[\operatorname{Pr}\left(Y_{1}=1 \mid T=1, X=x\right)\right]-E\left[\operatorname{Pr}\left(Y_{0}=1 \mid T=1, X=x\right)\right] \\
& =E\left[\frac{\Phi_{2}\left(x_{1} \tau_{1}, Z \gamma, \rho_{1}\right)-\Phi_{2}\left(x_{0} \tau_{0}, Z \gamma, \rho_{0}\right)}{F(Z \gamma)}\right]
\end{aligned}
$$

$$
\begin{aligned}
A T U & =E\left[\operatorname{Pr}\left(Y_{1}=1 \mid T=0, X=x\right)\right]-E\left[\operatorname{Pr}\left(Y_{0}=1 \mid T=0, X=x\right)\right] \\
& =E\left[\frac{\Phi_{2}\left(x_{1} \tau_{1},-Z \gamma,-\rho_{1}\right)-\Phi_{2}\left(x_{0} \tau_{0},-Z \gamma,-\rho_{0}\right)}{F(-Z \gamma)}\right]
\end{aligned}
$$

$$
\begin{aligned}
A T E & =E\left[\operatorname{Pr}\left(Y_{1}=1 \mid T=1, X=x\right)\right]-E\left[\operatorname{Pr}\left(Y_{0}=1 \mid T=0, X=x\right)\right] \\
& =E\left[F\left(x_{1} \tau_{1}\right)-F\left(x_{0} \tau_{0}\right)\right]
\end{aligned}
$$

where $\Phi_{2}$ is the cumulative function of a bivariate normal distribution and $F$ is the cumulative function of a bivariate normal distribution.

\section{Results and discussion}

\subsection{Descriptive statistics}

The experimental results show that 39 percent of farmers in the study area are risk-averse. Our estimate is comparable to the findings of a recent study by Jin, He, Gong, Xu, and He (2017) who used similar risk preference elicitation experimental games and found that 44 percent of the households in rural China are risk-averse. Table 2 depicts the mean values for the continuous variables and mean proportions for the binary variables under the two groups - purchasers and non-purchasers of WICI. We used the independent $\mathrm{t}$-test to assess whether the mean values or proportions of a given variable vary across the two groups of households.

The averages show that non-purchasers are less risk-averse than purchaser farmers. A significantly larger proportion of purchasers live in the same village with the insurance foreman. On average, the purchaser households have a higher number of economically active members than their non-purchaser counterparts. The average land and livestock holdings of the non-purchasers are

\begin{tabular}{|c|c|c|c|}
\hline Variables & $\begin{array}{c}\text { Non- } \\
\text { purchasers } \\
(\mathrm{N}=119) \\
\text { Mean }\end{array}$ & $\begin{array}{l}\text { Purchasers } \\
\left(\begin{array}{c}\mathrm{N}=120) \\
\text { Mean }\end{array}\right.\end{array}$ & Mean Diff. \\
\hline \multicolumn{4}{|l|}{ Variables of interest } \\
\hline \multicolumn{4}{|l|}{ Risk preferences } \\
\hline risk-taker & 0.479 & 0.400 & 0.079 \\
\hline risk-neutral & 0.193 & 0.150 & 0.043 \\
\hline risk-averse & 0.328 & 0.450 & $-0.122^{*}$ \\
\hline Mineral fertilizers use & 0.351 & 0.342 & 0.009 \\
\hline $\begin{array}{l}\text { Same village with insurance } \\
\text { foreman }\end{array}$ & 0.361 & 0.733 & $-0.372^{* * *}$ \\
\hline \multicolumn{4}{|l|}{ Control variables } \\
\hline age & 39.66 & 41.53 & -1.88 \\
\hline sex & 0.824 & 0.742 & 0.082 \\
\hline education & 0.378 & 0.408 & -0.030 \\
\hline active people & 2.403 & 3.042 & $-0.638^{* * *}$ \\
\hline asset holding $^{\mathrm{a}}$ & 15.06 & 15.76 & -0.70 \\
\hline tropical livestock unit ${ }^{\mathrm{b}}$ & 5.778 & 4.264 & $1.514^{* * *}$ \\
\hline land holding & 1.330 & 1.102 & $0.228^{* *}$ \\
\hline housing condition & 0.807 & 0.792 & 0.015 \\
\hline access to credit & 0.714 & 0.817 & $-0.102^{*}$ \\
\hline private transfer & 0.445 & 0.342 & 0.104 \\
\hline cooperative member & 0.723 & 0.675 & 0.048 \\
\hline iddir member ${ }^{c}$ & 0.950 & 0.975 & -0.025 \\
\hline equb member ${ }^{c}$ & 0.471 & 0.442 & 0.029 \\
\hline ties with training office & 0.101 & 0.642 & $-0.541^{* * *}$ \\
\hline own TV or radio & 0.269 & 0.467 & $-0.198^{* * *}$ \\
\hline own phone & 0.773 & 0.733 & 0.040 \\
\hline
\end{tabular}
significantly higher than that of the purchasers. With regard to access to credit and ownership of television or radio, on average, the purchaser farmers are better off than the non-purchasers. In
Table 2

Mean and mean difference tests of the variables included in the analyses.

Notes: Appendix Table A1 in the supplementary materials presents the full description of each variable.

a Asset holding is an index (scaled between 0 and 100) constructed based on binary variables indicating the household's ownership of; stove, television, radio, telephone, fridge, and drip-irrigation equipment.

$\mathrm{b}$ We measured livestock holding using Tropical Livestock Unit (TLU) based on Jahnke (1982) conversion factors as Camel 1.0; horse 0.8; cattle and mule 0.7 each; donkey 0.5 ; pig 0.2 ; sheep and goat 0.1 each; and chicken 0.01 .

c Self-help groups, which are widely prevailing informal institutions in Ethiopia.

addition, a significantly higher proportion of the purchasers have personal ties with someone who works at the training and development office of the R4 WICI project.

\subsection{Estimation results}

The selection equation (farmers' WICI purchase decision) and the outcome equation(s) (farmers' risk-aversion) of the SEM and ESP models are estimated simultaneously. To facilitate detailed discussion, the results from the selection and outcome models are presented separately in the following sub-sections.

\subsubsection{Selection model - Demand for WICI}

Our analyses are based on a sample of purchasers and nonpurchasers that reside in tabias where the WICI scheme exists. Table 3 presents the estimation results on the selection (WICI uptake) equation after adjusting for the effects of observable and unobservable heterogeneity. We find a robust positive effect of living in the same village with the foreman (our instrumental variable) on the probability of farmers' WICI uptake. The ESP is our preferred model for the reasons described in Section 4.2.2, and we discuss the results from column (2) in Table 3 . The results show that farmers who live in the same village with the insurance foreman have 17 percentage points higher probability of purchasing WICI. A falsification test proposed by Di Falco, Veronesi, and Yesuf (2011) was executed to establish the admissibility of our instrument. Our IV does not enter as a statistically significant variable when included in a probit regression on the risk-aversion of 
Table 3

Selection model: Purchase of WICI.

\begin{tabular}{|c|c|c|c|c|}
\hline \multirow[t]{2}{*}{ Variables } & \multicolumn{2}{|c|}{$\begin{array}{c}\text { (1) } \\
\text { SEM } \\
\text { Probit (WICI uptake) }\end{array}$} & \multicolumn{2}{|c|}{$\begin{array}{c}\text { (2) } \\
\text { ESP } \\
\text { Probit (WICI uptake) }\end{array}$} \\
\hline & Coeff. & AME & Coeff. & AME \\
\hline same village with foreman & $\begin{array}{c}0.8021^{* * *} \\
(0.2054)\end{array}$ & $\begin{array}{c}0.1808^{* * * *} \\
(0.0433)\end{array}$ & $\begin{array}{c}0.7439^{* * *} \\
(0.2357)\end{array}$ & $\begin{array}{c}0.1665^{* * *} \\
(0.0497)\end{array}$ \\
\hline age & $\begin{array}{c}0.0265 \\
(0.0163)\end{array}$ & $\begin{array}{c}0.0060 \\
(0.0037)\end{array}$ & $\begin{array}{c}0.0175 \\
(0.0168)\end{array}$ & $\begin{array}{c}0.0039 \\
(0.0037)\end{array}$ \\
\hline sex & $\begin{array}{l}-0.2644 \\
(0.2679)\end{array}$ & $\begin{array}{l}-0.0596 \\
(0.0603)\end{array}$ & $\begin{array}{l}-0.2531 \\
(0.2872)\end{array}$ & $\begin{array}{l}-0.0566 \\
(0.0638)\end{array}$ \\
\hline education & $\begin{array}{c}0.2248 \\
(0.2156)\end{array}$ & $\begin{array}{c}0.0507 \\
(0.0493)\end{array}$ & $\begin{array}{c}0.1893 \\
(0.3055)\end{array}$ & $\begin{array}{c}0.0424 \\
(0.0684)\end{array}$ \\
\hline active people & $\begin{array}{c}0.1294^{*} \\
(0.0729)\end{array}$ & $\begin{array}{c}0.0292^{*} \\
(0.0161)\end{array}$ & $\begin{array}{c}0.1545^{*} \\
(0.0890)\end{array}$ & $\begin{array}{l}0.0346^{*} \\
(0.0201)\end{array}$ \\
\hline asset holding & $\begin{array}{l}-0.0041 \\
(0.0111)\end{array}$ & $\begin{array}{l}-0.0009 \\
(0.0025)\end{array}$ & $\begin{array}{c}0.0002 \\
(0.0108)\end{array}$ & $\begin{array}{c}0.0001 \\
(0.0024)\end{array}$ \\
\hline tropical livestock unit & $\begin{array}{c}-0.0829^{*} \\
(0.0434)\end{array}$ & $\begin{array}{c}-0.0187^{* *} \\
(0.0095)\end{array}$ & $\begin{array}{c}-0.1120^{* * *} \\
(0.0293)\end{array}$ & $\begin{array}{c}-0.0251^{* * * *} \\
(0.0063)\end{array}$ \\
\hline land holding & $\begin{array}{c}-0.2703^{*} \\
(0.1583)\end{array}$ & $\begin{array}{c}-0.0609^{*} \\
(0.0357)\end{array}$ & $\begin{array}{l}-0.2357 \\
(0.1528)\end{array}$ & $\begin{array}{l}-0.0527 \\
(0.0346)\end{array}$ \\
\hline housing condition & $\begin{array}{c}0.0772 \\
(0.3019)\end{array}$ & $\begin{array}{c}0.0174 \\
(0.0680)\end{array}$ & $\begin{array}{c}0.2024 \\
(0.2663)\end{array}$ & $\begin{array}{c}0.0453 \\
(0.0596)\end{array}$ \\
\hline access to credit & $\begin{array}{c}0.4014^{*} \\
(0.2311)\end{array}$ & $\begin{array}{c}0.0905^{*} \\
(0.0519)\end{array}$ & $\begin{array}{l}0.4649^{*} \\
(0.2429)\end{array}$ & $\begin{array}{l}0.1040^{*} \\
(0.0541)\end{array}$ \\
\hline private transfer & $\begin{array}{c}0.0080 \\
(0.2726)\end{array}$ & $\begin{array}{c}0.0018 \\
(0.0614)\end{array}$ & $\begin{array}{c}0.0917 \\
(0.2507)\end{array}$ & $\begin{array}{c}0.0205 \\
(0.0560)\end{array}$ \\
\hline cooperative member & $\begin{array}{c}-0.6758^{* *} \\
(0.2696)\end{array}$ & $\begin{array}{c}-0.1524^{* * *} \\
(0.0578)\end{array}$ & $\begin{array}{c}-0.5734^{* *} \\
(0.2478)\end{array}$ & $\begin{array}{c}-0.1283^{* *} \\
(0.0537)\end{array}$ \\
\hline iddir member & $\begin{array}{c}1.0999 \\
(0.9376)\end{array}$ & $\begin{array}{c}0.2480 \\
(0.2078)\end{array}$ & $\begin{array}{l}1.6156^{* *} \\
(0.6988)\end{array}$ & $\begin{array}{l}0.3615^{* *} \\
(0.1507)\end{array}$ \\
\hline equb member & $\begin{array}{c}0.2085 \\
(0.2523)\end{array}$ & $\begin{array}{c}0.0470 \\
(0.0563)\end{array}$ & $\begin{array}{c}0.2442 \\
(0.3050)\end{array}$ & $\begin{array}{c}0.0546 \\
(0.0682)\end{array}$ \\
\hline ties with training office & $\begin{array}{l}1.9116^{* * *} \\
(0.2996)\end{array}$ & $\begin{array}{c}0.4310^{* * *} \\
(0.0447)\end{array}$ & $\begin{array}{c}2.0568^{* * *} \\
(0.3222)\end{array}$ & $\begin{array}{c}0.4602^{* * *} \\
(0.0555)\end{array}$ \\
\hline own TV or radio & $\begin{array}{c}0.2298 \\
(0.3193)\end{array}$ & $\begin{array}{c}0.0518 \\
(0.0720)\end{array}$ & $\begin{array}{c}0.0222 \\
(0.2828)\end{array}$ & $\begin{array}{c}0.0050 \\
(0.0633)\end{array}$ \\
\hline own mobile phone & $\begin{array}{c}-0.1732 \\
(0.2974)\end{array}$ & $\begin{array}{r}-0.0390 \\
(0.0667)\end{array}$ & $\begin{array}{r}-0.1613 \\
(0.3155)\end{array}$ & $\begin{array}{l}-0.0361 \\
(0.0702)\end{array}$ \\
\hline Constant & $\begin{array}{c}-2.6104^{* * *} \\
(0.9843)\end{array}$ & & $\begin{array}{c}-2.9502^{* * *} \\
(0.9083)\end{array}$ & \\
\hline
\end{tabular}

Notes: Robust standard errors in parentheses.

${ }^{* * *} \mathrm{p}<0.01,{ }^{* *} \mathrm{p}<0.05,{ }^{*} \mathrm{p}<0.1$.

SEM, ESP and AME stand for simultaneous equations model, endogenous switching probit and average marginal effect respectively.

non-purchaser farmers (Appendix Table A2 in the supplementary materials).

The average marginal effects (AME) for the remaining variables in the selection equation, i.e. the effects of changes in variables on the probability of WICI uptake, are also shown in Table 3 next to each coefficient estimate. ${ }^{9}$ Households with a larger number of economically active family members have a higher probability of WICI uptake. Household income is an increasing function of economically active family members Manlagñit (2004) that may avail more financial resources for agricultural investments such as the purchase of WICI. Farmers' demand for WICI increases with their access to credit. Credit relaxes the households' liquidity constraints, and hence can significantly increase the probability that households purchase WICI. This result is similar to the findings of Giné et al. (2008) in rural India and Hill et al. (2013) in rural Ethiopia. The positive effect of iddir membership on the households' demand for WICI in Ethiopia is also documented in studies by Dercon, Hill, Clarke, Outes-Leon, and Taffesse (2014) and Berg, Blake, and Morsink (2017).

Farmers that have ties with a person who works in the training office of the R4 WICI pilot project are more likely to purchase WICI.

\footnotetext{
9 The coefficient estimates on our control variables are merely correlational and could only serve as suggestive results for further enquiry. Hence, we are interested only in the direction of the associations.
}

This may work through the person's role in familiarizing a farmer about the existing agricultural risk management technology in the study area. In particular, farmers' contact with the training personnel of the project can facilitate the flow of information that could positively shape their knowledge and attitudes towards WICI, and ultimately can affect their decision to purchase WICI. However, we cannot rule out the possible effect of WICI uptake on the ability of farmers to meet and know people who work in the project. On the contrary, the number of livestock owned and cooperative membership are negatively and significantly correlated with farmers' WICI uptake. Households with more livestock can rely on the sale of their livestock to buffer the effects of climate shocks Sango, Hoffmann, and Christiaensen (2007), and so they may prefer to opt against the uptake of WICI. The negative correlation between farmers' membership of a cooperative organization and WICI uptake may imply that farmers consider cooperatives as a substitute for purchasing the insurance product.

\subsubsection{Risk-aversion model}

Our outcome variable takes the form of either an ordinal risk preferences variable ordered in accordance with farmers' levels of risk-aversion or a binary variable coded as 1 to represent riskaversion and 0 otherwise (see Section 3.2). The SEM and ESP estimations were used to estimate the binary WICI uptake and the 
ordinal or binary risk-aversion equations simultaneously. The ESP is our preferred model for two main reasons. First, the likelihood ratio test of independence between the selection and outcome equations shows that SEM is not a relevant specification for our data. Second, the Wald test rejects the joint independence of the risk-aversion equations in the two regimes and the selection model. The test provides evidence that the naïve ordered probit or probit estimates (reported in Appendix Table A4) are biased and inconsistent due to the presence of unobserved factors affecting the selection process and farmers' risk-aversion simultaneously. Moreover, the test also reveals that ESP is more appropriate model specification than describing the behavior of all farmers with a single risk-aversion equation - as it is the case under SEM. Therefore, to economize space, we only discuss the results from the ESP model.

In the risk-aversion (outcome) equations for the two regimes (purchasers and non-purchasers), there are a few variables that significantly correlate with farmers' risk preferences (Table 4). As a formal and informal means of relaxing liquidity constraints, purchaser households' access to credit and equb are negatively correlated with their risk-aversion. The positive correlation between agricultural landholding and risk-aversion is observed under both regimes. In addition, risk-aversion of the non-purchasers and asset holdings are also positively correlated. Land and asset holdings are proxies for wealth and income-generating capacity of rural households. A positive correlation between income and risk-aversion of households is also presented in Bosch-Domènech and Silvestre (2006). Households' personal ties with the training personnel of the WICI scheme and ownership of radio or television - proxies for the households' access to information - are negatively correlated with risk-aversion of the non-purchasers group. The other covariates do not enter as significant predictors in the riskaversion equations of the purchaser and non-purchaser farmers.

The error terms in the equations determining the uptake of WICI and farmers' risk-aversion of the non-purchasers are perfectly negatively correlated $\left(\rho_{0}=-1\right)$ and statistically significant. The correlation among the error terms in the selection equation and the risk-aversion model of the purchasers $\left(\rho_{1}\right)$ is also negative but it is not statistically significant. These findings imply that selfselection exists only for the non-purchaser farmers. Non-purchaser farmers are significantly more risk-averse than a potentially random sample. ${ }^{10}$

\subsubsection{The effect of WICI on risk-aversion}

Table 5 reports the ATT, ATU, and ATE estimates, derived from the ESP model as described in Eqs. (5)-(7), respectively. Purchaser farmers are on average 43 percentage points less likely to be riskaverse compared with the counterfactual scenario of nonpurchaser farmers. This translates to a reduction in the riskaversion of the purchasers by around 50 percent compared with what it would have been had they not purchased WICI. The nonpurchaser farmers would have also attained, on average, 26 percentage points reduction in their risk-aversion if they had taken up WICI. This translates to a 79 percent decline in the probability of risk-aversion from the initial sub-population of risk-averse farmers in the non-purchasers group. Moreover, the average riskaversion of farmers would have been lowered by 35 percentage points had all farmers in the study area decided to purchase the insurance product. Put differently, if the insurance scheme had covered every farmer in the study area, the probability of riskaversion would have been around 90 percent lower compared with

\footnotetext{
$\overline{10}$ Without addressing the endogeneity of risk preferences, risk-aversion may appear to have a positive effect on WICI uptake and may compel us to state that more risk-averse farmers are likely to purchase WICI (Appendix Table A3 in the supplementary materials).
}

the counterfactual scenario of none of the farmers had purchased WICI. If we do not take into account the simultaneity and selfselection biases in analysing the impact of WICI uptake on farmers' risk-aversion, we will have a perversely signed average treatment effect estimate (Appendix Table A4 in the supplementary materials).

The WICI improves households' economic outcomes since the insurance payouts during negative rainfall shocks can stabilize income and ensure smooth consumption (Janzen \& Carter, 2018). As a crucial determinant of economic outcomes, markets dictate the formation of values, tastes and preferences by affecting what individuals must do or be to sustain their livelihood (Gerber \& Jackson, 1993; Bowles, 1998; Palacios-Huerta \& Santos, 2004; Melesse \& Cecchi, 2017). In the absence of crop insurance markets, farmers will "self-insure" (Rosenzweig \& Binswanger, 1993), which may lead to formation of risk-averse attitudes. As such, WICI uptake may change farmers' interpretation of the operating environment for farming and ultimately reduces their risk-aversion. This also has implications on the future uptake of WICI by farmers. Our study and studies by Giné et al. (2008) and Hill et al. (2013) find that demand for index-based crop insurance product is low among risk-averse individuals, which is contrary to that for indemnity crop insurance products (Clarke, 2016). Therefore, in the context where there is uninterrupted access to index-based crop insurance market, purchasers are more likely to continue buying the insurance product in the future due to them having lower risk-aversion. However, in the event that access to WICI market is interrupted due to termination of the R4 initiative or other external shocks, we cannot rule out the possibility that the reduction in farmers' risk-aversion is reversible as farmers may revert to "self-insurance".

\subsubsection{The effect of WICI on observed risk-taking behavior}

In this section, we examine to what extent the effect of WICI on farmers' risk-aversion is translated into their economic risk-taking behavior in daily life. We use the decision to apply mineral fertilizers as an observed risk-taking behavior of farmers. Since the early work by Rosenzweig and Binswanger (1993), it has been shown that farmers in developing countries employ a self-insurance mechanism by avoiding high-risk high-return agricultural technologies to minimize income variability. Mineral fertilizers perfectly match the definition of high-risk high-return agricultural technologies. According to Fosu-Mensah and Mensah (2016), a profound yield-enhancing effect of mineral fertilizers is realized in soils with sufficient moisture. In the context of rainfed agriculture, their finding may mean that the desirable yield- and income-boosting effects of mineral fertilizers are associated with the presence of favorable weather conditions during the agricultural season. Otherwise, households may not recover what they spend to purchase mineral fertilizers in the presence of insufficient rainfall (Alem, Bezabih, Kassie, \& Zikhali, 2010). Therefore, in an environment characterized by erratic weather conditions, taking farmers' decision to adopt mineral fertilizer as our outcome variable enables us to examine whether WICI uptake has a positive effect on farmers' risky but profitable agricultural investment decisions. Our binary outcome variable for fertilizer use takes the value of 1 if the farmer used mineral fertilizers during the production year in the survey period, and 0 otherwise.

The positive and statistically significant impact of WICI on the adoption of mineral fertilizer matches our expectation. ${ }^{11}$ Table 6 shows that the likelihood of mineral fertilizer use by purchasers of WICI increased by 60 percentage points. Similarly, the adoption rate

\footnotetext{
11 The parameter estimates of the ESP model are reported in Table A5 in the supplementary materials.
} 
Table 4

Effect estimates for the covariates under the risk-aversion equations.

\begin{tabular}{|c|c|c|c|c|c|c|}
\hline \multirow{4}{*}{ Variables } & \multicolumn{4}{|c|}{$\begin{array}{c}(1) \\
\text { SEM }\end{array}$} & \multicolumn{2}{|c|}{$\begin{array}{l}(2) \\
\text { ESP }\end{array}$} \\
\hline & \multicolumn{4}{|c|}{ Ordered Probit (Risk preferences) } & \multicolumn{2}{|c|}{ Probit (Risk-aversion) } \\
\hline & \multirow[t]{2}{*}{ Coeff. } & \multicolumn{3}{|c|}{ Average Marginal Effect (AME) } & \multirow{2}{*}{$\begin{array}{c}\text { Purchasers } \\
\text { Coeff. }\end{array}$} & \multirow{2}{*}{$\begin{array}{c}\text { Non-purchasers } \\
\text { Coeff. }\end{array}$} \\
\hline & & Risk-taking & Risk-neutral & Risk-aversion & & \\
\hline purchase WICI & $\begin{array}{l}-0.1639 \\
(1.7387)\end{array}$ & $\begin{array}{c}0.0597 \\
(0.6320)\end{array}$ & $\begin{array}{l}-0.0017 \\
(0.0175)\end{array}$ & $\begin{array}{l}-0.0580 \\
(0.6146)\end{array}$ & & \\
\hline age & $\begin{array}{c}0.0104 \\
(0.0139)\end{array}$ & $\begin{array}{l}-0.0038 \\
(0.0050)\end{array}$ & $\begin{array}{c}0.0001 \\
(0.0002)\end{array}$ & $\begin{array}{c}0.0037 \\
(0.0049)\end{array}$ & $\begin{array}{l}-0.0018 \\
(0.0194)\end{array}$ & $\begin{array}{l}-0.0167 \\
(0.0154)\end{array}$ \\
\hline $\operatorname{sex}$ & $\begin{array}{l}-0.0099 \\
(0.2494)\end{array}$ & $\begin{array}{c}0.0036 \\
(0.0908)\end{array}$ & $\begin{array}{l}-0.0001 \\
(0.0026)\end{array}$ & $\begin{array}{l}-0.0035 \\
(0.0882)\end{array}$ & $\begin{array}{c}0.1757 \\
(0.4175)\end{array}$ & $\begin{array}{l}-0.1108 \\
(0.3429)\end{array}$ \\
\hline education & $\begin{array}{c}0.0803 \\
(0.1860)\end{array}$ & $\begin{array}{l}-0.0293 \\
(0.0676)\end{array}$ & $\begin{array}{c}0.0008 \\
(0.0022)\end{array}$ & $\begin{array}{c}0.0284 \\
(0.0657)\end{array}$ & $\begin{array}{c}0.1399 \\
(0.3391)\end{array}$ & $\begin{array}{l}-0.1159 \\
(0.2663)\end{array}$ \\
\hline active people & $\begin{array}{c}0.0876 \\
(0.0600)\end{array}$ & $\begin{array}{l}-0.0319 \\
(0.0213)\end{array}$ & $\begin{array}{c}0.0009 \\
(0.0011)\end{array}$ & $\begin{array}{c}0.0310 \\
(0.0209)\end{array}$ & $\begin{array}{c}0.1477 \\
(0.0899)\end{array}$ & $\begin{array}{l}-0.0735 \\
(0.0721)\end{array}$ \\
\hline asset holding & $\begin{array}{c}0.0049 \\
(0.0091)\end{array}$ & $\begin{array}{l}-0.0018 \\
(0.0033)\end{array}$ & $\begin{array}{c}0.0001 \\
(0.0001)\end{array}$ & $\begin{array}{c}0.0017 \\
(0.0032)\end{array}$ & $\begin{array}{l}-0.0042 \\
(0.0112)\end{array}$ & $\begin{array}{c}0.0386^{* * *} \\
(0.0145)\end{array}$ \\
\hline tropical livestock unit & $\begin{array}{c}-0.0302 \\
(0.0400)\end{array}$ & $\begin{array}{c}0.0110 \\
(0.0143)\end{array}$ & $\begin{array}{l}-0.0003 \\
(0.0005)\end{array}$ & $\begin{array}{l}-0.0107 \\
(0.0140)\end{array}$ & $\begin{array}{c}0.0084 \\
(0.0640)\end{array}$ & $\begin{array}{c}0.0178 \\
(0.0302)\end{array}$ \\
\hline land holding & $\begin{array}{c}0.1487 \\
(0.1569)\end{array}$ & $\begin{array}{l}-0.0541 \\
(0.0578)\end{array}$ & $\begin{array}{c}0.0016 \\
(0.0028)\end{array}$ & $\begin{array}{c}0.0526 \\
(0.0556)\end{array}$ & $\begin{array}{c}0.3484^{*} \\
(0.2093)\end{array}$ & $\begin{array}{c}0.2678^{*} \\
(0.1585)\end{array}$ \\
\hline housing condition & $\begin{array}{l}-0.1073 \\
(0.2182)\end{array}$ & $\begin{array}{c}0.0391 \\
(0.0794)\end{array}$ & $\begin{array}{l}-0.0011 \\
(0.0027)\end{array}$ & $\begin{array}{l}-0.0380 \\
(0.0771)\end{array}$ & $\begin{array}{l}-0.0560 \\
(0.3725)\end{array}$ & $\begin{array}{l}-0.1067 \\
(0.2782)\end{array}$ \\
\hline access to credit & $\begin{array}{c}-0.5262^{*} \\
(0.2713)\end{array}$ & $\begin{array}{l}0.1916^{*} \\
(0.1000)\end{array}$ & $\begin{array}{l}-0.0055 \\
(0.0078)\end{array}$ & $\begin{array}{c}-0.1861^{*} \\
(0.0952)\end{array}$ & $\begin{array}{c}-0.8426^{* *} \\
(0.3640)\end{array}$ & $\begin{array}{l}-0.1938 \\
(0.2754)\end{array}$ \\
\hline private transfer & $\begin{array}{c}0.0429 \\
(0.1688)\end{array}$ & $\begin{array}{l}-0.0156 \\
(0.0615)\end{array}$ & $\begin{array}{c}0.0005 \\
(0.0018)\end{array}$ & $\begin{array}{c}0.0152 \\
(0.0597)\end{array}$ & $\begin{array}{c}0.3215 \\
(0.3058)\end{array}$ & $\begin{array}{l}-0.1995 \\
(0.2487)\end{array}$ \\
\hline cooperative member & $\begin{array}{c}0.1077 \\
(0.4147)\end{array}$ & $\begin{array}{l}-0.0392 \\
(0.1516)\end{array}$ & $\begin{array}{c}0.0011 \\
(0.0050)\end{array}$ & $\begin{array}{c}0.0381 \\
(0.1468)\end{array}$ & $\begin{array}{c}0.2579 \\
(0.3442)\end{array}$ & $\begin{array}{c}0.2287 \\
(0.2802)\end{array}$ \\
\hline iddir member & $\begin{array}{c}0.0603 \\
(0.5895)\end{array}$ & $\begin{array}{l}-0.0220 \\
(0.2144)\end{array}$ & $\begin{array}{c}0.0006 \\
(0.0061)\end{array}$ & $\begin{array}{c}0.0213 \\
(0.2084)\end{array}$ & $\begin{array}{l}-0.6984 \\
(1.0722)\end{array}$ & $\begin{array}{l}-0.2619 \\
(0.5744)\end{array}$ \\
\hline equb member & $\begin{array}{l}-0.2570 \\
(0.2566)\end{array}$ & $\begin{array}{c}0.0936 \\
(0.0944)\end{array}$ & $\begin{array}{l}-0.0027 \\
(0.0046)\end{array}$ & $\begin{array}{l}-0.0909 \\
(0.0909)\end{array}$ & $\begin{array}{c}-0.6361^{* *} \\
(0.3220)\end{array}$ & $\begin{array}{l}-0.3840 \\
(0.2742)\end{array}$ \\
\hline ties with training office & $\begin{array}{c}0.5394 \\
(1.0368)\end{array}$ & $\begin{array}{c}-0.1964 \\
(0.3732)\end{array}$ & $\begin{array}{c}0.0057 \\
(0.0101)\end{array}$ & $\begin{array}{c}0.1908 \\
(0.3651)\end{array}$ & $\begin{array}{c}0.2331 \\
(1.3863)\end{array}$ & $\begin{array}{c}-0.6350^{*} \\
(0.3541)\end{array}$ \\
\hline own TV or radio & $\begin{array}{l}-0.2505 \\
(0.2272)\end{array}$ & $\begin{array}{c}0.0912 \\
(0.0828)\end{array}$ & $\begin{array}{l}-0.0026 \\
(0.0040)\end{array}$ & $\begin{array}{l}-0.0886 \\
(0.0802)\end{array}$ & $\begin{array}{l}-0.2023 \\
(0.3253)\end{array}$ & $\begin{array}{c}-1.0390^{* * *} \\
(0.3234)\end{array}$ \\
\hline own mobile phone & $\begin{array}{c}0.0061 \\
(0.2321)\end{array}$ & $\begin{array}{l}-0.0022 \\
(0.0845)\end{array}$ & $\begin{array}{c}0.0001 \\
(0.0024)\end{array}$ & $\begin{array}{c}0.0021 \\
(0.0821)\end{array}$ & $\begin{array}{l}-0.3848 \\
(0.3685)\end{array}$ & $\begin{array}{c}0.0533 \\
(0.3700)\end{array}$ \\
\hline Constant & & & & & $\begin{array}{c}0.7835 \\
(2.6599)\end{array}$ & $\begin{array}{l}-0.0015 \\
(0.7831)\end{array}$ \\
\hline rho $\left(\rho_{i}\right)$ & & & & & $\begin{array}{l}-0.4714 \\
(1.3241) \\
\end{array}$ & $\begin{array}{c}-1^{* * *} \\
(2.43 \mathrm{E}-11)\end{array}$ \\
\hline Observations & & & & & & \\
\hline Test of $\rho_{i}=0$ ( $p$ value $)$ & & & & & & \\
\hline
\end{tabular}

Notes: Robust standard errors in parentheses.

${ }^{* * *} \mathrm{p}<0.01,{ }^{* *} \mathrm{p}<0.05,{ }^{*} \mathrm{p}<0.1$

SEM, ESP and AME stand for simultaneous equations model, endogenous switching probit and average marginal effect respectively.

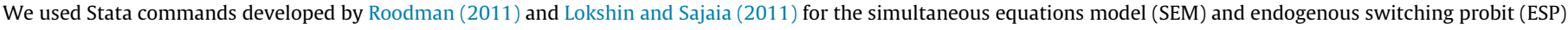
analyses, respectively.

Tests of joint independence ( $p$ values) are based on the likelihood ratio and Wald tests under the SEM and ESP models respectively.

Table 5

Treatment effect estimates: Impact of WICI on risk-aversion.

\begin{tabular}{lll}
\hline Treatment effect estimates & Observations & Estimate \\
\hline Average Treatment Effect on the Treated (ATT) & 120 & $-0.4267^{* * *}$ \\
& & $(0.0221)$ \\
& 119 & $-0.2620^{* * *}$ \\
Average Treatment Effect on the Untreated (ATU) & & $(0.0235)$ \\
& 239 & $-0.3506^{* * *}$ \\
Average Treatment Effect (ATE) & & $(0.0160)$
\end{tabular}

Notes: Standard errors in parentheses. ${ }^{* * *} \mathrm{p}<0.01$.

We used the Stata command developed by Lokshin and Sajaia (2011) for estimating the treatment effects.

of non-purchasers would have increased by 33 percentage points if they had taken-up WICI. These findings imply that the magnitude of the impact of WICI on the application of mineral fertilizer is larger
Table 6

Treatment effect estimates: Impact of WICI on mineral fertilizers use.

\begin{tabular}{lll}
\hline Treatment effect estimates & Observations & Estimate \\
\hline Average Treatment Effect on the Treated (ATT) & 120 & $\begin{array}{l}0.5958^{* * *} \\
(0.0249)\end{array}$ \\
Average Treatment Effect on the Untreated (ATU) & 119 & $\begin{array}{l}0.3295^{* * *} \\
(0.0226)\end{array}$ \\
& & $0.4617^{* * *}$ \\
Average Treatment Effect (ATE) & 239 & $(0.0159)$ \\
& &
\end{tabular}

Notes: Standard errors in parentheses. ${ }^{* * *} \mathrm{p}<0.01$.

We used the Stata command developed by Lokshin and Sajaia (2011) for estimating the treatment effects.

for purchaser farmers. Insuring all farmers in the study area would have increased the probability of mineral fertilizer application by 46 percentage points compared to the scenario where none of the 
households had purchased WICI. In this case, the adoption rate of mineral fertilizers in the study area would have been increased to 81 percent. $^{12}$ Our results show that farmers who purchased WICI are more likely to benefit from favorable agricultural seasons above and beyond non-purchasers because of their investments in yieldboosting agricultural technologies. Changes in risk-aversion may be a plausible mechanism through which WICI uptake causes an effect on farmers' risk-taking behavior in their agricultural investment decisions - proxied by adoption of mineral fertilizers.

We also examine the relative importance of farmers' WICI uptake, risk preferences and other observable characteristics in predicting their decision to adopt mineral fertilizer. ${ }^{13}$ This endeavor allows us to explore whether WICI uptake is more important in predicting mineral fertilizer adoption than farmers' risk preferences. ${ }^{14}$ In such a scenario, risk-aversion may have little importance in explaining the impact of WICI on fertilizer adoption. Appendix Fig. A1 depicts the ranks of observed variables based on their relative importance in predicting farmers' decision to use mineral fertilizer. Our result supports previous findings by Liu (2013), Ward and Singh (2015), Brick and Visser (2015), Holden and Quiggin (2017), who show that risk preferences are the most important drivers of agricultural technology adoption. The importance of WICI uptake in predicting household decision to use mineral fertilizer is lower than the relative importance of farmers' risk preferences. Taking into account the results in the preceding section, our findings suggest that WICI uptake influences household decisions to adopt agricultural technologies mainly through its effect on risk preferences. Hence, risk preferences are influenced by crop insurance market arrangements where farmers operate. In turn, risk preferences determine household decisions to invest in high-risk but profitable agricultural technologies.

\section{Conclusion}

In the presence of uninsured climate risks, farmers in developing countries acquire their livelihood by engaging in low-risk lowreturn practices to provide "self-insurance" (Rosenzweig \& Binswanger, 1993), which may lead to formation of risk-averse attitudes. This economic behavior permanently keeps them in low-income low-investment vicious cycle (Carter \& Barrett, 2006; Dercon \& Christiaensen, 2011). One focus area of active research has been analysing how preferences are formed and change in the presence of external stimuli. There has been a long-standing argument about the importance of policies and institutions in shaping households' preferences (Roumasset, 1976; Eswaran \& Kotwal, 1986; Bowles, 1998; Palacios-Huerta \& Santos, 2004; Mendola, 2007). However, in the context of formal climate risk transfer mechanisms, previous studies that examined the relationship between the uptake of WICI and real-life risk-taking behavior of farmers considered risk preferences as given, which restricts an empirical inquiry into change in risk preferences as a plausible mechanism. By taking the case of Ethiopia, this study contributes to the existing literature on the causes of change in risk preferences by providing valuable insight into the structural relationship between a program intervention that facilitates access to WICI and farmers' risk-aversion.

Empirically isolating the causal effect of farmers' WICI uptake on their risk-aversion using observational data is a challenging task. Simultaneity bias risk-aversion of farmers determine their

\footnotetext{
12 If our analysis had not considered self-selection bias, the effect of WICI on mineral fertilizer use would have appeared to be negatively signed (Appendix Table A6 in the supplementary materials).

${ }^{13}$ The random forest (RF) method, which we used for the analysis, is explained in Appendix B.

${ }^{14}$ We thank the anonymous reviewer for this insightful suggestion.
}

WICI uptake decision and self-selection bias the presence of unobserved farmer characteristics that affect both WICI uptake and risk-aversion - are serious concerns. We used the ESP model to address these concerns. Our results from the selection equation show that promotion and training officers of WICI can play a significant role in getting farmers to take-up the insurance product. The treatment effect estimates provide evidence for a significant reduction in the risk-aversion of farmers in response to the uptake of WICI.

We find that farmers who purchased WICI are less likely to be risk-averse compared to non-purchaser farmers. Similarly, nonpurchasers would have attained a significant reduction in their risk-aversion if they had taken up the insurance product. Overall, if the insurance scheme had covered every farmer in the study area, the probability of risk-aversion would have been around 90 percent lower relative to the counterfactual scenario where none of the farmers had purchased WICI. We also find that WICI has a positive and statistically significant effect on farmers' real-life risk taking behavior - mineral fertilizer use. We argue that WICI uptake reduces farmers' risk-aversion by plausibly changing their interpretation of the operating environment for farming. In turn, changes in farmers' risk-aversion is arguably a major channel through which WICI uptake influences their investment decisions on high-risk high-return agricultural technologies.

Our study contributes to evidence-informed policymaking that intends to spur economic growth in developing countries in the era of frequent and severe climate shocks. Risk preferences are linked to economic development by influencing households' production, consumption and labor supply decisions that, in turn, determine the accumulation of human, physical and financial capital. The role of climate risk management policies in general and WICI in particular in the poverty alleviation and economic development can also be channeled through their effects on risk preferences. Thus, investments on policies and strategies aiming to improve farmers' access and uptake of formal climate risk transfer mechanisms can have long-term effect on the development prospects of agrarian economies by bringing up desirable individual economic behavior that may enable households to break out of poverty traps and enjoy virtuous cycle of increasing income.

Since our analyses are based on cross sectional data, we can assess only the variation in risk-aversion of a given farmer in relation to WICI uptake at a given point in time. There is a need for further investigation on the within-farmer effects of WICI uptake on risk-aversion using panel data. In so doing, one can robustly identify whether the observed change in farmers' risk-aversion in relation to purchase of WICI is attributed to change in the risk preference of a given farmer across time. Furthermore, the special basis-risk fund of the WICI scheme under the R4 initiative, which we have evaluated in this study, makes it distinct from the common index-based insurance products that do not have such a feature. Future research on the impact of WICI without the basis-risk fund on farmers' risk-aversion would show the generalizability of our findings. Moreover, comparative assessments on the adoption and impact of WICI with and without the basis risk fund would also be insightful concerning the identification of effective and efficient design feature of the insurance product.

\section{CRediT authorship contribution statement}

Kaleab K. Haile: Conceptualization, Methodology, Investigation, Formal analysis, Writing - original draft, Data curation, Project administration, Funding acquisition. Eleonora Nillesen: Conceptualization, Writing - review \& editing, Supervision. Nyasha Tirivayi: Conceptualization, Writing - review \& editing, Supervision. 


\section{Declaration of Competing Interest}

The authors declare that they have no known competing financial interests or personal relationships that could have appeared to influence the work reported in this paper.

\section{Acknowledgement}

Haile gratefully acknowledges funding from the Netherlands Fellowship Program (NFP) to finance the field work of this study as part of his PhD studies. We thank the editor, Arun Agrawal, and two anonymous referees for their insightful reviews. This article has substantially benefited from helpful comments from the participants at the UNU-MERIT third internal conference in Maastricht and CESifo conference on Poverty, Inequality and their Associations with Disaster and Climate Change in Venice. We would also like to thank Halefom Nigus for his contribution in the data collection.

\section{Appendix A. Supplementary data}

Supplementary data associated with this article can be found, in the online version, athttps://doi.org/10.1016/j.worlddev.2020. 104930.

\section{References}

Aakvik, A., Heckman, J. J., \& Vytlacil, E. J. (2005). Estimating treatment effects for discrete outcomes when responses to treatment vary: An application to Norwegian vocational rehabilitation programs. Journal of Econometrics, 125 $15-51$.

Alem, Y., Bezabih, M., Kassie, M., \& Zikhali, P. (2010). Does fertilizer use respond to rainfall variability? Panel data evidence from Ethiopia. Agricultural Economics, 41(2), 165-175.

Barnett, B. J., Barrett, C. B., \& Skees, J. R. (2008). Poverty traps and index-based risk transfer products. World Development, 36(10), 1766-1785.

Becker, G. S., \& Mulligan, C. B. (1997). The endogenous determination of time preference. The Quarterly Journal of Economics, 09, 729-758.

Berg, E., Blake, M., \& Morsink, K. (2017). Risk sharing and the demand for insurance: Theory and experimental evidence from Ethiopia. CSAE Working Paper WPS 2017-01-2.

Bosch-Domènech, A., \& Silvestre, J. (2006). Do the wealthy risk more money? An experimental comparison. In C. Schultz \& K. Vind (Eds.), Institutions, Equilibria and Efficiency. Berlin, Heidelberg: Springer. volume Studies in.

Bowles, S. (1998). Endogenous preferences: The cultural consequences of markets and other economic institutions. Journal of Economic Literature, 36(1), 75-111.

Brick, K., \& Visser, M. (2015). Risk preferences, technology adoption and insurance uptake: A framed experiment. Journal of Economic Behavior and Organization, $118,383-396$.

Brick, K., Visser, M., \& Burns, J. (2012). Risk aversion: Experimental evidence from South African fishing communities. American Journal of Agricultural Economics, 94(1), 133-152.

Brown, J., Fang, C., \& Gomes, F. (2012). Risk and returns to education. NBER Working Paper No. w18300.

Callen, M. Isaqzadeh, M., Long J. D., \& Sprenger, C. (2014). Violence and risk preference: Experimental evidence from Afghanistan. American Economic Review, 104(1), 123-148.

Camerer, C. F., \& Hogarth, R. M. (1999). The effects of financial incentives in experiments: A review and capital labor production framework. Journal of Risk and Uncertainty, 19(1-3), 7-42.

Cameron, L., \& Shah, M. (2015). Risk taking behavior in the wake of natura disasters. Journal of Human Resources, 50(2), 484-515.

Carter, M. R., \& Barrett, C. B. (2006). The economics of poverty traps and persistent poverty: Empirical and policy implications. Journal of Development Studies, 42 (2), 178-199.

Cassar, A., Healy, A., \& Kessler, C. V. (2017). Trust, risk, and time preferences after a natural disaster: Experimental evidence from Thailand. World Development, 94, 90-105.

Chantarat, S., Barrett, C. B., Mude, A. G., \& Turvey, C. G. (2007). Using weather index insurance to improve drought response for famine prevention. American Journal of Agricultural Economics, 89(5), 1262-1268.

Charness, G., Gneezy, U., \& Imas, A. (2013). Experimental methods: Eliciting risk preferences. Journal of Economic Behavior and Organization, 87, 43-51.

Clarke, B. D. J. (2016). A theory of rational demand for index insurance. American Economic Journal: Microeconomics, 8(1), 283-306.
Cohn, A., Engelmann, J., Fehr, E., \& Maréchal, M. A. (2015). Evidence for countercyclical risk aversion: An experiment with financial professionals. American Economic Review, 105(2), 860-885.

Cole, B. S., Giné, X., Tobacman, J., Topalova, P., Townsend, R., \& Vickery, J. (2013). Barriers to household risk management: Evidence from India. American Economic Journal: Applied Economics, 5(1), 104-135.

Dave, C., Eckel, C. C., Johnson, C. A., \& Rojas, C. (2010). Eliciting risk preferences: When is simple better? Journal of Risk and Uncertainty, 41(3), 219-243.

de Janvry, A., Fafchamps, M., \& Sadoulet, E. (1991). Peasant household behaviour with missing markets: Some paradoxes explained. The Economic Journal, 101 (409), 1400-1417.

Dercon, S., \& Christiaensen, L. (2011). Consumption risk, technology adoption and poverty traps: Evidence from Ethiopia. Journal of Development Economics, 96(2), $159-173$.

Dercon, S., Hill, R. V., Clarke, D., Outes-Leon, I., \& Taffesse, A. S. (2014). Offering rainfall insurance to informal insurance groups: Evidence from a field experiment in Ethiopia. Journal of Development Economics, 106, 132-143.

Di Falco, S., Veronesi, M., \& Yesuf, M. (2011). Does adaptation to climate change provide food security? A micro-perspective from Ethiopia. American Journal of Agricultural Economics, 93(3), 825-842.

Eckel, C. C., El-gamal, M. A., \& Wilson, R. K. (2009). Risk loving after the storm: A Bayesian-Network study of Hurricane Katrina evacuees. Journal of Economic Behavior \&' Organization, 69, 110-124.

Eswaran, M., \& Kotwal, A. (1986). Access to capital and agrarian production organisation. The Economic Journal, 96(382), 482-498.

Fosu, A. K. (2015). Growth, inequality and poverty in sub-Saharan Africa: Recent progress in a global context. Oxford Development Studies, 43(1), 44-59.

Fosu-Mensah, B. Y., \& Mensah, M. (2016). The effect of phosphorus and nitrogen fertilizers on grain yield, nutrient uptake and use efficiency of two maize (Zea mays L.) varieties under rain fed condition on Haplic Lixisol in the forest savannah transition zone of Ghana. Environmental Systems Research, 5(22), $1-17$.

Friedman, D. D. (1962). Price theory. New York: Aldine Publishing Company.

Gerber, E. R., \& Jackson, J. E. (1993). Endogenous preferences and the study of institutions. The American Political Science Review, 87(3), 639-656.

Giné, X., Townsend, R., \& Vickery, J. (2008). Patterns of rainfall insurance participation in rural India. World Bank Economic Review, 22(3), 539-566.

Gloede, O., Menkhoff, L., \& Waibel, H. (2015). Shocks, individual risk attitude, and vulnerability to Poverty among rural households in Thailand and Vietnam. World Development, 71, 54-78.

Greene, W. H. (2012). Econometric analysis. Pearson Education Limited, Essex, England, seventh edition.

Hanaoka, C., Shigeoka, H., \& Watanabe, Y. (2018). Do risk preferences change? Evidence from the Great East Japan Earthquake. American Economic Journal: Applied Economics, 10(2), 298-330.

Heckman, J. J. (1978). Dummy endogenous variables in a simultaneous equation system. Econometrica, 46(6), 931-959.

Hertel, T. W. \& Rosch, S. D. (2010). Climate Change, agriculture and poverty. World Bank Policy Research Working Paper 5468

Hill, R. V., Hoddinott, J., \& Kumar, N. (2013). Adoption of weather-index insurance: Learning from willingness to pay among a panel of households in rural Ethiopia. Agricultural Economics, 44, 385-398.

Hill, R. V., \& Viceisza, A. (2012). A field experiment on the impact of weather shocks and insurance on risky investment. Experimental Economics, 15, 341-371.

Holden, S. T., \& Quiggin, J. (2017). Climate risk and state-contingent technology adoption: Shocks, drought tolerance and preferences. European Review of Agricultural Economics, 44(2), 285-308.

Huang, C. L., Raunikar, R., \& Misra, S. (1991). The application and economic interpretation of selectivity model. American Journal of Agricultural Economics, 73(2), 496-501.

Jahnke, H. E. (1982). Livestock production systems and livestock development. Kiel: Kieler Wissenschaftsverlag Vauk.

Jakiela, P., \& Ozier, O. (2019). The impact of violence on individual risk preferences: Evidence from a natural experiment. The Review of Economics and Statistics, 101 (3), 547-559.

Janzen, S. A., \& Carter, M. R. (2018). After the drought: The impact of microinsurance on consumption smoothing and asset protection. American Journal of Agricultural Economics, 1-21.

Jin, J., He, R., Gong, H., Xu, X., \& He, C. (2017). Farmers' risk preferences in rural China: Measurements and determinants. International Journal of Environmental Research and Public Health, 14(713), 1-11.

Jin, J., Wang, W., \& Wang, X. (2016). Farmers' risk preferences and agricultural weather index insurance uptake in rural China. International Journal of Disaster Risk Science, 7(4), 366-373.

Karlan, D., Osei, R., Osei-akoto, I., \& Udry, C. (2014). Agricultural decions after relaxing credit and risk constraints. The Quarterly Journal of Economics, 129(2), 597-652.

Krackhardt, D. (1998). Endogenous preferences: A structural approach. In J. Halpern \& N. Stern (Eds.). Debating rationality: Non-rational aspects of organizational decision making (pp. 239-247). Cornell University Press.

Liu, E. M. (2013). Time to change what to sow: Risk preferences and technology adoption decisions of cotton farmers in China. The Review of Economics and Statistics, 95(4), 1386-1403.

Lokshin, M., \& Sajaia, Z. (2011). Impact of interventions on discrete outcomes: Maximum likelihood estimation of the binary choice models with binary endogenous regressors. The Stata Journal, 11(3), 368-385. 
Madajewicz, M., Tsegay, A. H., \& Lee, R. (2017). Managing risks in smallholder agriculture: The impacts of R4 on livelihoods in Tigray, Ethiopia from 2012 to 2016. Oxfam America Evaluation Report. Technical report, WFP/OA.

Maddala, G. S. (1983). Limited-dependent and qualitative variables in econometrics. New York: Cambridge University Press.

Malmendier, U., \& Nagel, S. (2011). Depression babies: Do macroeconomic experiences affect risk taking? The Quarterly Journal of Economics, 126(1), 373-416.

Manlagñit, M. C. V. (2004). The Role of other economically active household members in poverty alleviation. Philippine Institute for Development Studies. Discussion paper series No. 2004-03.

Masih, I., Maskey, S., \& Trambauer, P. (2014). A review of droughts on the African continent: A geospatial and long-term perspective. Hydrology and Earth System Sciences, 18, 3635-3649.

Melesse, M. B., \& Cecchi, F. (2017). Does market experience attenuate risk aversion? Evidence from landed farm households in Ethiopia. World Development, 98(453), 447-466.

Mendola, M. (2007). Farm household production theories: A Review of Institutional and Behavioural responses. Asian Development Review, 24(1), 49-68.

Meyer, J. (2014). The theory of risk and risk aversion. In M. Machina \& K. Viscusi (Eds.). Handbook of the Economics of Risk and Uncertainty (pp. 99-133). Elsevier B.V.

Miranda, A., \& Rabe-Hesketh, S. (2006). Maximum likelihood estimation of endogenous switching and sample selection models for binary, ordinal, and count variables. The Stata Journal, 6(3), 285-308.

Mobarak, A. M., \& Rosenzweig, M. (2012). Selling formal insurance to the informally insured. Economic Growth Center. Yale University.

Moya, A. (2018). Violence, psychological trauma, and risk attitudes: Evidence from victims of violence in Colombia. Journal of Development Economics, 131, 15-27.

Netzer, N. (2009). Evolution of time preferences and attitudes toward risk. American Economic Review, 99(3), 937-955.

Nigus, H. Y., Nillesen, E., \& Mohnen, P. (2018). The effect of weather index insurance on social capital: Experimental evidence from Ethiopia. UNU-MERIT Working Paper No. 2018-007.

Nyikal, R. A., \& Kosura, W. O. (2005). Risk preference and optimal enterprise combinations in Kahuro division of Muranga district, Kenya. Agricultural Economics, 32, 131-140.

Odusola, A., Cornia, G. A., Bhorat, H., \& Conceição, P. (Eds.). (2017). Income inequality trends in sub-Saharan Africa: Divergence, determinants and consequences. New York: United Nations Development Programme, Regional Bureau for Africa.

Palacios-Huerta, I., \& Santos, T. J. (2004). A theory of markets, institutions, and endogenous preferences. Journal of Public Economics, 88, 601-627.
Roe, T. \& Graham-Tomasi, T. (1985). Yield risk in a dynamic model of the agricultural household. Center Discussion Paper No. 479.

Roodman, D. (2011). Fitting fully observed recursive mixed-process models with cmp. The Stata Journal, 11(2), 159-206.

Rosenzweig, M. R., \& Binswanger, H. P. (1993). Wealth, weather risk and the composition and profitability of agricultural investments. The Economic Journal, 103(416), 56-78.

Roumasset, J. A. (1976). Rice and risk. Decision making among low-income farmers. North Holland Publishing Co.

Sakha, S. (2019). Determinants of risk aversion over time: Experimental evidence from rural Thailand. Journal of Behavioral and Experimental Economics, 80 184-198.

Sango, D., Hoffmann, V., \& Christiaensen, L. (2007). Risks and coping strategies. In L. Christiaensen \& A. Sarris (Eds.), Rural household vulnerability and insurance against commodity risks: Evidence from the United Republic of Tanzania. Rome, Italy: Food and Agricultural Organization (FAO).

Schildberg-hörisch, H. (2018). Are risk preferences stable? Journal of Economic Perspectives, 32(2), 135-154.

Shiferaw, B., Tesfaye, K., Kassie, M., Abate, T., Prasanna, B. M., \& Menkir, A. (2014) Managing vulnerability to drought and enhancing livelihood resilience in subSaharan Africa: Technological, institutional and policy options. Weather and Climate Extremes, 3, 67-79.

Singh, I., Squire, L., \& Strauss, J. (1986). Agricultural household models: Extensions, applications, and policy. Johns Hopkins University Press.

Stigler, G. J., \& Becker, G. S. (1977). De gustibus non est disputandum. American Economic Review, 67(2), 76-90.

Suryabhagavan, K. V. (2017). GIS-based climate variability and drought characterization in Ethiopia over three decades. Weather and Climate Extremes, 15, 11-23.

Taylor, J., \& Adelman, I. (2003). Agricultural household models: Genesis, evolution, and extensions. Review of Economics of the Household, 1(1), 33-58.

Voors, M., Nillesen, E., Verwimp, P., Bulte, E., Lensink, R., \& Soest, D. V. (2012) Violent conflict and behavior: A field experiment in Burundi. American Economic Review, 102(2), 941-964.

Ward, P. S., \& Singh, V. (2015). Using field experiments to elicit risk and ambiguity preferences: Behavioural factors and the adoption of new agricultura technologies in rural India. Journal of Development Studies, 51(6), 707-724.

WFP/OA (2018). R4 rural resilience initiative quarterly report - October December 2018. Technical report.

Yesuf, M. \& Bluffstone, R. A. (2009). Poverty, risk aversion, and path dependence in low-income countries: Experimental evidence from Ethiopia. American Journal of Agricultural Economics, 91(4), 1022-1037. 